\title{
D2-40, a novel lymphatic endothelial marker: identification of lymphovascular invasion and relationship with axillary metastases in breast cancer
}

\author{
D2-40, um novo marcador endotelial linfático: identificação de invasão linfática e relação com metástases \\ axilares em câncer de mama
}

Vanessa Fortes Zschaber Marinho'; Fernanda Squárcio Fernandes Sanches²; Gislene Fátima Silva Rocha ${ }^{3}$; Konradin Metze ${ }^{4}$; Helenice Gobbi ${ }^{5}$

\begin{abstract}
key words
Neoplastic Iymphatic

invasion

Mammary carcinoma

Immunohistochemistry

D2-40

CD31

\section{abstract}

Background: Studies of lymphatic vessels were limited by the lack of specific markers. Recently, they have become possible due to the release of new D2-40 antibody, a selective marker for lymphatic endothelium. The aim of our study was to compare neoplastic invasion in lymphatic and blood vessels detected in hematoxylin and eosin (H\&E) and immunohistochemistry-stained sections. Methodology: A total of 123 cases of invasive mammary carcinomas were studied and sorted out into three subgroups according to axillary staging (macrometastasis, micrometastasis and lymph node negative). Lymphatic vessel invasion (LVI) and blood vessel invasion (BVI) were initially evaluated in histological $\mathrm{H} \& \mathrm{E}$ and immunohistochemistry-stained sequential sections. Lymphatic and blood vessel invasions were assessed by immunohistochemistry, employing D2-40 and CD31 antibodies, respectively. LVI and BVI were related to size, type, histologic grade of primary tumors, and the presence of metastasis. Results: LVI was detected through $\mathrm{H} \& \mathrm{E}$ staining procedure in $17 / 123$ cases $(13.8 \%)$, and through immunohistochemistry procedure in $35 / 123$ cases $(28.5 \%)(\mathrm{kappa}=0.433)$. BVI was detected through $\mathrm{H} \& \mathrm{E}$ in $5 / 123$ cases $(4.1 \%)$, and through immunohistochemistry in $19 / 123$ cases $(15.4 \%)($ kappa $=0.198)$. LVI and BVI were positively related to higher histologic grade of primary tumors $(p<0.05)$. LVI was also positively related to the presence of macrometastasis. Conclusion: The detection of lymphatic and blood vessel invasions through immunohistochemistry employing D2-40 and CD31 was higher than the detection through $\mathrm{H \& E}$, and it was related to higher tumor grade and metastasis in axillary lymph nodes.
\end{abstract}

\section{resumo}

Introdução: Estudos de vasos linfáticos eram limitados pela ausência de marcadores endoteliais linfáticos específicos. Recentemente, eles se tornaram possiveis após liberação comercial do novo anticorpo D2-40, marcador seletivo para endotélio linfático. O objetivo do nosso estudo foi comparar invasão neoplásica em vasos linfáticos e sanguíneos detectada em secções coradas pela hematoxilina e eosina (HE) e imuno-histoquímica (IIQ). Materiais e métodos: Foram estudados 123 casos de carcinomas mamários invasores subdivididos em três subgrupos de acordo com o estadiamento axilar: macrometástases (Mac-Met), micrometástases (Mic-Met) e linfonodo negativo (LNN). Invasão de vasos linfáticos (IVL) e de vasos sangüíneos (IVS) foi inicialmente avaliada em secções histológicas coradas pela HE e através da IIQ realizada em cortes seqüenciais. A invasão de vasos linfáticos e sanguíneos foi avaliada pela imuno-histoquímica, empregando-se respectivamente os anticorpos D2-40, e CD31. IVL e IVS foram relacionadas com tamanho tumoral, tipo e grau histológico dos tumores primários e com a presença de metástases. Resultados: IVL foi observada pela HE em $17 / 123$ casos $(13,8 \%)$ e pela IIQ em 35/123 casos $(28,5 \%)$ (kappa $=0,433)$. IVS foi observada pela HE em $5 / 123$ casos $(4,1 \%)$ e pela IIQ em 19/123 casos $(15,4 \%)$ (kappa $=0,198)$. IVL e IVS estavam positivamente relacionadas com maior grau histológico dos tumores primários $(\mathrm{p}<0,05)$. IVL também estava positivamente relacionada com a presença de macrometástases. Conclusão: A deteç̧ão IIQ, respectivamente por D2-40 e CD31, de invasão de vasos linfáticos e sanguíneos foi maior que a detecção feita em cortes corados pela HE e relacionou-se com maior grau tumoral e metástases em linfonodos axilares.

\section{unitermos}

Embolia neoplásica

linfática

Carcinoma mamário

Imuno-histoquímica

$D 2-40$

CD31

\footnotetext{
1. Anatomopathologist; master's degree in medical pathology from Universidade Federal de Minas Cerais (UFMC); doctorate student at the post-graduation program in pathology, Department of Anatomic Pathology, School of Medicine, UFMG.

2. Scientific initiation scholar from Fundação de Amparo à Pesquisa de Minas Cerais (FAPEMIC) (PROBIC), Department of Anatomic Pathology, School of Medicine, UFMG.

3. Scientific initiation scholar from Conselho Nacional de Desenvolvimento Cientifico e Tecnológico (CNPq) (PIBIC), Department of Anatomic Pathology, School of Medicine, UFMC

4. Doctor; professor at the Department of Pathology; fellow of the interdisciplinary group "Analytical Cellular Pathology", Universidade Estadual de Campinas (UNICAMP).

5. Doctor; assistant professor at the Department of Anatomic Pathology and Legal Medicine, School of Medicine, UFMG.

This work was conducted at the breast pathology laboratory, Department of Anatomic Pathology and Legal Medicine, School of Medicine, UFMG, with financial support of CNPq and FAPEMIC. It is part of the doctoral thesis "Fatores morfológicos e moleculares de carcinoma da mama relacionados a metástases em linfonodos axilares", presented at the post-graduation program in pathology, UFMG. Partial results were presented at the I Encontro Nacional de Pós-Graduação em Patologia, São Paulo, November 2006, and at the $96^{\text {th }}$ United States and Canadian Academy of Pathology, San Diego, Califórnia, March 2007.
} 


\section{Introduction}

The presence of lymph node metastasis represents a major criterion for evaluating the potential prognosis of breast cancer patients and predicts the choice of additional chemotherapy after surgery of primary tumor ${ }^{(19)}$. Tumorassociated lymphatic vessels are considered the main route of tumor cells to axillary lymph nodes. Lymphatic vessel invasion (LVI) by tumor cells is a prerequisite for dissemination via the lymphatic system ${ }^{(3,19)}$. Much is known about the formation of new blood vessels as a mechanism to support haematogenous spread and facilitate tumor growth. In contrast, little is known about the mechanisms involved in lymphatic spread(22).

LVI is known as an independent predictor of lymph node metastases in breast cancer. However, the identification of LVI can be difficult in hematoxylin and eosin (H\&E) stained slides. Usually, LVI identification is based on conventional $\mathrm{H} \& \mathrm{E}$ staining, and the diagnosis is based on the presence of tumor emboli within vascular channels lined by a single layer of endothelial cells without red blood cells. Retraction artifacts that isolate tumor aggregates due to tissue shrinkage during fixation are sometimes confused with the true tumor emboli in lymphatic vessels ${ }^{(4,23)}$.

Several markers of blood vessel endothelium have been used including CD31, CD34, and factor VIII-related antigen (von Willebrand factor or VWF). However, studies of lymphatic vessels have been limited by lack of specific lymphatic endothelial markers and the immunohistochemical identification of lymphatic vessels has been unreliable ${ }^{(5,19)}$. Recently, novel selective markers for lymphatic endothelium have been released, such as LYVE-1, prox 1 , and podoplanin(7). More recently, monoclonal antibody D2-40 was shown to selectively detect lymphatic vessels in breast and tonsillar tissue $^{(13,14)}$. In these studies, endothelium of lymphatic vessels was immunoreactive to D2-40, while, in contrast, blood and lymphatic vessels endothelium was reactive to CD31, CD34, and $\operatorname{VWF}^{(5,13,14)}$. D2-40 is an IgG2a monoclonal antibody generated against an oncofetal antigen M2A, which is normally expressed in the fetal testis and reexpressed in germ cell neoplasia ${ }^{(2)}$. D2-40 stains the endothelium of lymphatic vessels and lymphangiomas. In contrast, hemangiomas, glomus tumors, angiolipomas, pyogenic granulomas, and vascular malformations did not show any staining ${ }^{(13,14)}$.

Studies of various tumors have shown the potential clinical significance of blood and lymphatic vessels, suggesting that blood and lymphatic microvessel density correlates with tumor growth and metastasis $(5,16)$.
The aim of our study is to compare lymphatic and blood vessel neoplastic invasion in invasive mammary carcinomas using H\&E and immunohistochemical stained sections.

\section{Material and methods}

This study was conducted on 123 patients with invasive mammary carcinomas who had been submitted to surgical treatment (excisional biopsy, conservative breast surgery, and mastectomy) with axillary lymph node dissection at Hospital das Clínicas of Universidade Federal de Minas Gerais (UFMG), Brazil, between 1990 and 2004. This research was approved by the Ethics Committee of the University. We selected 41 cases diagnosed as axillary lymph node negative (LNN), 41 cases with micrometastases (Mic-Met [defined by The American Joint Committee on Cancer as neoplastic cell clusters measuring between 0.2 and $2 \mathrm{~mm}$ ), and 41 cases with macrometastases (Mac-Met [defined as neoplastic cell clusters larger than $2 \mathrm{~mm}])^{(12)}$, based on the original histopathologic examination. No case of isolated tumor cells in lymph nodes was included in this study.

We initially selected the cases with micrometastases, and after this selection we matched the same number of cases with macrometastases and lymph node negative. Mean age of patients, histologic type and tumor grade of cases of each group were similar. For all cases, the original $\mathrm{H \& E}$-stained sections of primary tumors and axillary lymph nodes were available for histologic review. The paraffin blocks were available for additional sections and immunohistochemical analysis. Special care was taken to include only specimens with sufficient amount of normal tissue surrounding the invasive tumor to evaluate peritumoral lymphatic (LVI) and blood (BVI) vessel invasions.

Cases were evaluated considering age of patients and tumor size (using the TNM system) ${ }^{(12)}$. Histologic analysis of primary breast carcinoma features included histologic type, histologic grade, and invasion of lymphatic and/or blood vessels. The histologic type of primary tumor was classified based on Page et al. (17) and the College of American Pathologists recommendations ${ }^{(10)}$, using rigid criteria for classification of special types. Tumor grade was determined using the Nottingham grading system ${ }^{(8)}$. The diameter of the microscopic field used for mitotic count was $0.44 \mathrm{~mm}$. Lymphatic and/or blood vessel invasion was assessed by two pathologists (VFZM and $H G)$, reviewing the $H \& E$ and immunohistochemicalstained sections using a double-headed microscope.

H\&E-stained sections of primary tumors were reviewed and new histologic sections were prepared for the 
immunohistochemical study. Immunohistochemistry (IHC) was performed on $4 \mu \mathrm{m}$ thickness sections, using monoclonal antibodies and the streptavidin-biotin peroxidase method. D2-40 (clone D2-40; Signet; 1:100) was used for lymphatic evaluation, and CD31 (clone JC/70A; Dako; 1:50), for blood and lymphatic vessel evaluation. CD31 sections were submitted to heat-induced epitope retrieval in citrate buffer pH6.0 for 25 minutes. Immunohistochemical reactions were developed with diaminobenzidine and sections were counterstained with Harrris hematoxylin. All immunostains were manually processed.

IHC using the monoclonal anti-cytokeratin antibody (clone AE1/AE3, Dako, USA) was also carried out on additional sections of all axillary lymph nodes initially classified as negative or with micrometastases.

The IHC-stained sections of all primary tumors and axillary lymph nodes were evaluated by the same pathologist without knowledge of axillary lymph node status. All lymph node positive, doubts, and $10 \%$ of negative lymph nodes, histologic type and grade of all primary tumors were reevaluated by two pathologists (VFZM and HG) using a double-headed microscope. Lymphatic and/or blood vessel invasion were considered evident if at least one tumor cell cluster was clearly visible in the vascular space. Vessels were considered lymphatic when the endothelium stained with both D2-40 and CD31 antibodies, without having red blood cells within the lumen. Small vessels were classified as blood vessels when the vascular endothelium stained only for the CD31 monoclonal antibody, was negative for D2-40, and presented red blood cells within the lumen.

Statistical analysis was performed using the Epi-info $6.04 \mathrm{~b}$ software. Kappa statistic test was used to compare blood and lymphatic neoplastic invasion in H\&E and IHC stained sections.

\section{Results}

Patients' ages ranged from 27 to 88 years (mean = 55.9 years and median $=52$ years). Sixty-five out of 123 patients (52.8\%) were postmenopausal. Most tumors (65 cases; $52.8 \%$ ) were classified as T2 (2 to $5 \mathrm{~cm}), 38$ cases (30.9\%) measured between 1 and $2 \mathrm{~cm}$, followed by tumors between 2 and $3 \mathrm{~cm}$ (29 cases; 23.6\%) (Table 1).

\section{Table 1 carcinomas according to axillary lymph node status}

\begin{tabular}{lccc}
\hline Characteristics & Mac-Met & Mic-Met & LNN \\
Menopausal status & $n(\%)$ & $n(\%)$ & $n(\%)$ \\
Premenopausal & & & $20(48.8)$ \\
Postmenopausal & $20(48.8)$ & $18(43.9)$ & $21(51.2)$ \\
Tumor size (TNM) & $21(51.2)$ & $23(56.1)$ & $17(41.5)$ \\
T1 & & & $18(43.9)$ \\
T2 & $10(24.4)$ & $17(41.5)$ & $6(14.6)$ \\
T3 & $24(58.5)$ & $23(56.1)$ & \\
Histologic type & $7(17.1)$ & $1(2.4)$ & $31(75.6)$ \\
Ductal NST & & & $3(7.3)$ \\
Special variants & $32(78.1)$ & $33(80.4)$ & $7(17.1)$ \\
Pure special type & $3(7.3)$ & $4(9.8)$ & $13(31.7)$ \\
Histologic grade & $6(14.6)$ & $4(9.8)$ & $19(46.3)$ \\
Low & & & $9(22)$ \\
Intermediate & $9(22)$ & $14(34.1)$ & $2(4.9)$ \\
High & $21(51.2)$ & $18(43.9)$ & $2(4.9)$ \\
LVI* (H\&E) & $11(26.8)$ & $9(22)$ & $9(22)$ \\
BVI* (H\&E) & $12(29.3)$ & $3(7.3)$ & $2(4.9)$ \\
LVI (IHC) & $2(4.9)$ & $1(2.4)$ & $41(100)$ \\
BVI (IHC) & $16(39)$ & $10(24.4)$ & $11(26.8)$ \\
Total & $6(14.6)$ & $41(100)$ & \\
\hline
\end{tabular}

Mac-Met: macrometastases; Mic-Met: micrometastases; LNN: Iymph node negative; $\mathrm{n}$ : number of cases; NST: non-special type; LVI: lymphatic vessel invasion; BVI: blood vessel invasion; H\&E: hematoxylin and eosin; IHC: immunohistochemistry; ${ }^{*} L V I$ detected by H\&E was statistically related to histologic grade ( $\mathrm{p}=0.013$ ) and BVI detected by H\&E was related only to tumor size $(\mathrm{p}=0.009)$. 
The most frequent histologic type of primary tumors was invasive ductal carcinoma non-special type (105 cases; $85.4 \%$ ), followed by special variants (10 cases; $8.1 \%$ ), and pure special types (8 cases; 6.5\%) (Table 1). The special types included four cases of invasive lobular, two cases of invasive tubular, one case of mucinous carcinoma and one case of apocrine carcinoma. The special variants were: lobular (two cases), tubular (three cases), mucinous (one case), apocrine (one case), micropapillary (two cases), mixed type micropapillary and mucinous (one case).

Intermediate histologic grade was the most common ( 58 cases; $47.2 \%$ ), followed by low grade ( 36 cases; $29.3 \%$ ), and high grade (29 cases; $23.6 \%$ ) (Table 1).

Results of the LVland BVlassessed by immunohistochemistry are summarized on Tables 1, 2 and $\mathbf{3}$.

LVI was found in H\&E-stained slides in $17 / 123$ cases (13.8\%), while BVI was observed in 5/123 tumors (4.1\%). LVI was detected in IHC-stained slides in 35/123 cases (28.5\%), while BVI was identified in 19/123 tumors (15.4\%). LVI and BVI were easier to identify in sections immunostained for D2-40 and CD31 than in the H\&Estained sections (Tables 1 to 4 ) (Figure).

LVI was positively related to the presence of metastases $(p=0.002)$ and was more frequently found in the subgroup with macrometastases (12/17 cases). No relationship was observed between BVI and the presence of metastases $(p=0.81)$, except when BVI was detected by immunostained sections ( $p=0.02)$. In these cases, BVI was more frequently found in the subgroup with micrometastases.

No relationship was observed between age of patients and LVI or BVI $(p>0.05)$. Similarly to age, no relationship was observed between LVI and histologic tumor type. LVI was more frequently seen in invasive ductal carcinoma of

\begin{tabular}{lccc} 
& $\begin{array}{l}\text { Lymphatic vessel invasion detected } \\
\text { on hematoxylin and eosin and } \\
\text { immunostained sections of } 123\end{array}$ \\
Table 2 & $\begin{array}{l}\text { imvasive mammary carcinomas } \\
\text { intive }\end{array}$ \\
\hline LVI & \multicolumn{3}{c}{ Immunohistochemistry } \\
& Positive & Negative & Total \\
H\&E & $n(\%)$ & $n(\%)$ & $n(\%)$ \\
\hline Positive & $14(11.4)$ & $3(2.4)$ & $17(13.8)$ \\
Negative & $21(17.1)$ & $85(69.1)$ & $106(86.2)$ \\
Total & $35(28.5)$ & $88(71.5)$ & $123(100)$ \\
\hline
\end{tabular}

LVI: lymphatic vessel invasion; $\mathrm{n}$ : number of cases; Kappa value: $0.433 ; 95 \%$ confidence interval: 0.229 to 0.636 . non-special type. No relationship was detected between $\mathrm{BVI}$ and histologic tumor type $(p>0.05)$. BVI was positively related to tumor size $(p=0.009)$, and more frequently found in tumors greater than $2 \mathrm{~cm}$. No relationship was observed between $\mathrm{LVI}$ and tumor size $(p>0.05)$.

Blood vessel invasion detected on hematoxylin and eosin and immunostained sections of 123 Table 3 invasive mammary carcinomas

\begin{tabular}{lccc}
\hline BVI & \multicolumn{3}{c}{ Immunohistochemistry } \\
& Positive & Negative & Total \\
H\&E & $n(\%)$ & $n(\%)$ & $n(\%)$ \\
Positive & $3(2.4)$ & $2(1.7)$ & $5(4.1)$ \\
Negative & $16(13)$ & $102(82.9)$ & $118(95.9)$ \\
Total & $19(15.4)$ & $104(84.6)$ & $123(100)$ \\
\hline
\end{tabular}

BVI: blood vessel invasion; $\mathrm{n}$ : number of cases; Kappa value: $0.198 ; 95 \%$ confidence interval: -0.144 to 0.541 .

Lymphatic and blood vessel invasion
detected by hematoxylin and eosin
and immunohistochemistry in 123
invasive mammary carcinomas stratified
according to axillary lymph node status:
macrometastases, micrometastases and
lymph node negative

\begin{tabular}{lccc}
\hline & Mac-Met & Mic-Met & LNN \\
& $n(\%)$ & $n(\%)$ & $n(\%)$ \\
LVI (H\&E) & $12(29.3)$ & $3(7.3)$ & $2(4.9)$ \\
LVI (IHC) & $16(39)$ & $10(24.4)$ & $9(22)$ \\
BVI (H\&E) & $2(4.9)$ & $1(2.4)$ & $2(4.9)$ \\
BVI (IHC) & $6(14.6)$ & $11(26.8)$ & $2(4.9)$ \\
Total & $41(100)$ & $41(100)$ & $41(100)$ \\
\hline
\end{tabular}

Mac-Met: macrometastases; Mic-Met: micrometastases; LNN: lymph node negative; $\mathrm{n}$ : number of cases; LVI: lymphatic vessel invasion; BVI: blood vessel invasion; H\&E: hematoxylin and eosin; IHC: immunohistochemistry.

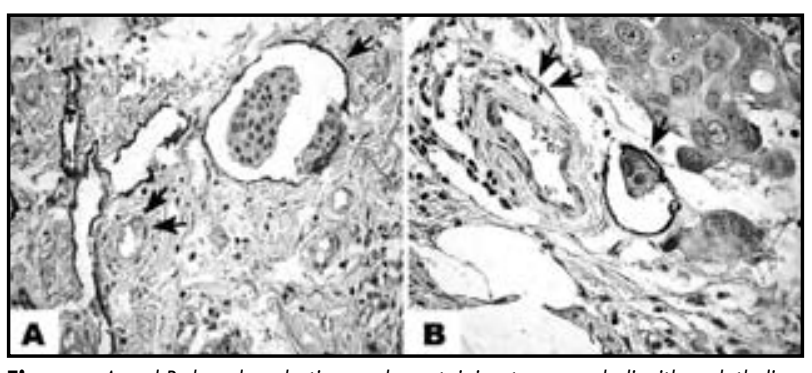

Figure - $A$ and $B$ show lymphatic vessels containing tumor emboli with endothelium positive for D2-40 (arrow), adjacent to blood vessels with endothelium negative for D2-40 (double arrow) - 400x 
LVI was positively related to high-grade tumors both in $\mathrm{H} \& \mathrm{E}$ and IHC studies $(p=0.0006$ and $p=0.04)$. BVI detected on $\mathrm{H} \& \mathrm{E}$-stained slides was related to increase in tumor size $(p=0.009)$ and high-grade tumors $(p=0.009)$.

\section{Discussion}

In the present study, we used the novel lymphatic endothelial immunomarker D2-40 and the CD31 antibody to identify lymphatic invasion in formalin-fixed paraffin-embedded breast carcinomas by performing immunohistochemistry.

D2-40 is considered a novel selective marker for endothelial lymphatic cells and does not react with endothelial cells of blood vessels ${ }^{(13)}$. Our study confirmed that D2-40 selectively stains the endothelium of lymphatic vessels, which is covered with flattened endothelial cells without red blood cells in the lumen. Furthermore, immunoreactivity by D2-40 antibody was useful in detecting lymphatic vessels in sections from formalin-fixed and paraffin-embedded blocks. Our results showed that D2-40 is a reliable and useful tool to accurately diagnose lymphatic invasion in invasive breast cancer and they are in agreement with findings of other studies $(1,4,16)$.

Our results demonstrated that tumor emboli, both in lymphatic and blood vessels, were easier to identify in the D2-40 and CD31 immunostained sections than in H\&Estained slides. This is important for the differential diagnosis with tumor retraction artifacts. Isolated tumor aggregates due to tissue shrinkage during fixation are sometimes confused with true tumor emboli in lymphatic vessels $s^{(1,4,9}$, 23). Because artifacts may occur at the tumor margin, some lymphatic neoplastic emboli that would be missed in the $\mathrm{H} \& \mathrm{E}$-stained sections evaluation were more easily detected in the D2-40 stained sections. It has long been suggested that lymph vessel invasion, as a diagnostic reproducible feature, should only be considered outside tumor margin ${ }^{(13,}$ ${ }^{22)}$. Acs et al.(1) proposed that apparent retraction artifacts of the stroma from cells of invasive breast carcinoma on routine histologic sections are not a phenomenon merely due to inadequate fixation as currently believed. Rather, they probably signify biologic changes that alter tumorstromal interactions and contribute to lymphatic spread and tumor progression ${ }^{(1,6,18)}$.

In our experience, the use of lymphatic endothelial markers should be considered the gold standard for lymph vascular invasion ${ }^{(11,15,21)}$. They should be used in addition to $\mathrm{H} \& \mathrm{E}$ assessment of lymphatic invasion when studying LVI detection. The kappa score obtained in our study showed only moderate agreement regarding the lymphatic vessel invasion and poor agreement regarding blood vessel invasion, when compared to $\mathrm{H} \& \mathrm{E}$-stained sections. The increased accuracy of LVI detection using immunohistochemistry for D2-40 and podoplanin was also demonstrated in other studies evaluating breast carcinomas $^{(4,6,9,18,20)}$ and other tumors such as melanomas and gastric cancer ${ }^{(11,15,21,23)}$.

In our study, the presence of lymphatic invasion detected in both H\&E and IHC sections was associated with high histologic grade. Vleugel et al. also reported lymphatic vascular invasion associated with high tumor grade ${ }^{(22)}$. Instead of being explained by retraction artifacts, as mentioned by Acs et al. ${ }^{(1)}$, this correlation could be explained by the biologic properties of tumors with more aggressive features ${ }^{(19,22)}$. This could lead to the speculation that fast-growing and high-grade tumors produce more growth factors and offer a bigger clonal variety of tumor cells capable of invading lymphatic vessels compared with low-grade, slow-growing tumors ${ }^{(22)}$. In our study, blood vessel invasion was related to tumor size in $\mathrm{H \& E}$-stained sections. A higher blood vessel formation is necessary during tumor growth ${ }^{(19)}$, so the pathophysiology of tumorrelated blood vessels is different from that of lymphatic vessels. Capillaries are feeder vessels that ensure tissue viability, and promote growth and nutrition in malignant tumors. Lymphatic vessels, on the other hand, are draining vessels that are not essential for tumor metabolism and therefore would not provide any advantage for tumor growth or survival ${ }^{(2,22)}$.

To our knowledge, this is the first study that assessed lymphatic invasion in breast cancer evaluating cases stratified in subgroups according to axillary lymph node status (macrometastases, micrometastases, and lymph node negative). Lymphatic vessel invasion was positively related to status of axillary lymph nodes. The detection of lymphatic invasion was superior in IHC-stained sections than in $\mathrm{H \& E}$, in all subgroups. Lymphatic invasion detected by both $\mathrm{H \& E}$ and $\mathrm{IHC}$ was superior in the subgroup with macrometastases ( $39 \%$ by IHC and $29.3 \%$ by H\&E) compared with micrometastases or lymph node negative subgroup. Our results showed that lymphatic invasion detected by D2-40 staining could more reliably predict lymph node metastases than H\&E-stained sections ${ }^{(1)}$. In our study, the presence of lymphatic invasion related to axillary lymph node metastases and should be considered in patients selected for sentinel lymph node biopsy. 
In conclusion, our results confirm that D2-40 is a selective marker for lymphatic vessel endothelium and is a reliable and useful tool for identification of lymphatic tumor emboli in breast carcinomas. Immunohistochemistry for D2-40 is superior to H\&E for lymph vascular neoplastic invasion identification. LVI is related to tumors with more aggressive features, indicating a potential for lymphatic metastatic spread, axillary lymph node metastases, and poor prognosis.

\section{Acknowledgments}

We are grateful to Sandra J. Olson for reviewing the English manuscript.

\section{References}

1. ACS, G. et al. Extensive retraction artifact correlates with lymphatic invasion and nodal metastasis and predicts poor outcome in early stage breast carcinoma. Am J Surg Pathol, v. 31, n. 1, p. 12940, 2007.

2. AGARWAL, B. et al. Lymphangiogenesis does not occur in breast cancer. Am J Surg Pathol, v. 29, n. 11, p. 1449-55, 2005.

3. AOKI, Y., TOSATO, G. Lymphatic regeneration: new insights from VEGFR-3 blockade. J Natl Cancer Inst, v. 97, n. 1, p. 2-3, 2005.

4. ARNAOUT-ALKARAIN, A. et al. Significance of lymph vessel invasion identified by the endothelial lymphatic marker D2-40 in node negative breast cancer. Mod Pathol, v. 20, n. 2, p. 183-91, 2007.

5. CHOl, W. W. et al. Angiogenic and lymphangiogenic microvessel density in breast carcinoma: correlation with clinicopathologic parameters and VEGF-family gene expression. Mod Pathol, v. 18, n. 1, p. 143-52, 2005.

6. CLARIJS, R.; RUITER, D. J.; de WAAL, R. M. Lymphangiogenesis in malignant tumours: does it occur? J Pathol, v. 193, n. 2, p. 143-6, 2001.

7. CUNNICK, G. H. et al. Lymphangiogenesis and breast cancer metastasis. Histol Histopathol, v. 17, n. 3, p. 863-70, 2002.

8. ELSTON, C. W.; ELLIS, I. O. Pathological prognostic factors in breast cancer. I. The value of histological grade in breast cancer: experience from a large study with long-term follow-up. Histopathology, v.19, n.5, p.403-10, 1991.

9. EVANGELOU, E.; KYZAS, P. A.; TRIKALINOS, T. A. Comparison of the diagnostic accuracy of lymphatic endothelial markers: Bayesian approach. Mod Pathol, v. 18, n. 11, p. 1490-7, 2005.

10. FITZGIBBONS, P. L. et al. Prognostic factors in breast cancer. College of American Pathologists Consensus Statement 1999. Arch Pathol Lab Med, v. 124, n. 7, p. 966-78, 2000.

11. GIORGADZE, T. A. et al. Lymphatic vessel density is significantly increased in melanoma. J Cutan Pathol, v. 31, n. 10, p. 672-7, 2004.
12. GREENE, F. L. et al. Breast. In: AJCC Cancer Staging Manual. $6^{\text {th }}$ ed. New York: Springer, 2002. Cap. 25; p. 223-40.

13. KAHN, H. J., MARKS, A. A new monoclonal antibody, D2-40, for detection of lymphatic invasion in primary tumors. Lab Invest, v. 82, n. 9, p. 1255-7, 2002.

14. KAHN, H. J.; BAILEY, D.; MARKS, A. Monoclonal antibody D2-40, a new marker of lymphatic endothelium, reacts with Kaposi's sarcoma and a subset of angiosarcomas. Mod Pathol, v. 15, n. 4, p. 434-40, 2002.

15. NIAKOSARI, F. etal. Detection of lymphatic invasion in primary melanoma with monoclonal antibody D2-40: a new selective immunohistochemical marker of lymphatic endothelium. Arch Dermatol, v. 141, n. 4, p.440-4, 2005.

16. NISATO, R. E.; TILLE, J. C.; PEPPER, M. S. Lymphangiogenesis and tumor metastasis. Thromb Haemost, v. 90, n. 4, p. 591-7, 2003.

17. PAGE, D. L.; JENSEN, R. A.; SIMPSON, J. F. Routinely available indicators of prognosis in breast cancer. Breast Cancer Res Treat, v. 51, n. 3, p. 195-208, 1998.

18. PEPPER, M. S. Lymphangiogenesis and tumor metastasis: myth or reality? Clin Cancer Res, v. 7, n. 3, p. 462-8, 2001.

19. SCHOPPMANN, S. F. et al. Prognostic value of lymphangiogenesis and lymphovascular invasion in invasive breast cancer. Ann Surg, v. 240, n. 2, p. 30612, 2004.

20. van den EYNDEN, G. G. et al. Distinguishing blood and lymph vessel invasion in breast cancer: a prospective immunohistochemical study. Br J Cancer, v. 94, n. 11, p. 1643-9, 2006.

21. van der AUWERA, I. et al. Tumor lymphangiogenesis in inflammatory breast carcinoma: a histomorphometric study. Clin Cancer Res, v. 11, n. 21, p. 7637-42, 2005.

22. VLEUGEL, M. M. et al. Lack of lymphangiogenesis during breast carcinogenesis. J Clin Pathol, v. 57, n. 7, p. 746-51, 2004.

23. YONEMURA, Y. et al. Evaluation of lymphatic invasion in primary gastric cancer by a new monoclonal antibody, D2-40. Hum Pathol, v. 37, n. 9, p. 1193-9, 2006.

\begin{tabular}{l|l} 
Mailing address \\
\hline & Helenice Cobbi \\
& Departamento de Anatomia Patológica, Faculdade de Medicina da UFMG \\
& Av. Alfredo Balena, 190 \\
CEP 30130-100 - Belo Horizonte-MG & \\
Tel.: (31) 3409-9118 & Fax: (31) 3409-9664 \\
e-mail: hgobbi@medicina.ufmg.br; vanessa.zschaber@gmail.com
\end{tabular}

